\title{
Who Are the Doctoral Students Who Drop Out? Factors Associated with the Rate of Doctoral Degree Completion in Universities
}

\author{
Robin Wollast ${ }^{1}$, Gentiane Boudrenghien ${ }^{1}$, Nicolas Van der Linden ${ }^{2}$, Benoît Galand ${ }^{1}$, Nathalie Roland ${ }^{1}$, Christelle \\ Devos $^{1}$, Mikaël De Clercq ${ }^{1}$, Olivier Klein ${ }^{2}$, Assaad Azzi $^{2}, \&$ Mariane Frenay ${ }^{1}$ \\ ${ }^{1}$ Psychological Research Institute, Faculty of Psychology and Education, Université catholique de Louvain, Belgium \\ ${ }^{2}$ Center for Social and Cultural Psychology, Faculty of Psychological Science and Education, Université libre de \\ Bruxelles, Belgium \\ Correspondence: Robin Wollast, Psychological Research Institute, Faculty of Psychology and Education, Place du \\ Cardinal Mercier 10, Boîte L3.05.01, 1348 Louvain-La-Neuve, Belgium. E-mail: robin.wollast@uclouvain.be and \\ mariane.frenay@uclouvain.be
}

Received: July 18, 2018

doi:10.5430/ijhe.v7n4p143
Accepted: August 12, 2018

Online Published: August 15, 2018

URL: https://doi.org/10.5430/ijhe.v7n4p143

\begin{abstract}
The issue of considerable dropout rate in doctoral programs is well documented across a large number of countries. However, few studies address the factors associated with doctoral completion among Non-U.S. countries, multiple universities and fields of research. Nor do they investigate the interactions between these factors. The present paper aimed to overcome these limitations and analyzed the population of doctoral students in all disciplines of the two largest universities of the French-speaking Community of Belgium $(\mathrm{N}=1509)$. Specifically, we focused on several factors: gender, nationality, marital status, master grade, whether students continued at the same university when transitioning to the doctoral degree, whether they continued in the same field, age at registration, research field and funding (i.e., type of funding and associated job requirements). Findings indicate that four factors (marital status, master grade, research field and funding) are directly associated with dropout rate when all factors are considered jointly in the same model. Furthermore, results indicate that some of these factors, such as the marital status and gender, interact. In addition, we found that an accumulation of risk factors leads to a massive increase in dropout rates. Finally, a time course analysis revealed that the highest dropout rate occurs during the first two years and is related to the absence of funding or scholarship. The results, limits and futures perspectives are discussed.
\end{abstract}

Keywords: doctoral study, persistence, attrition, higher education, quantitative methods

\section{Introduction}

$\mathrm{PhD}$ students are usually high achievers, who are among the brightest and most successful students. Moreover, they are subjected to a highly selective process (Ali \& Kohun, 2006; Golde, 2000). However, compared to all other degrees, the rate of completion in doctoral studies, which is estimated at $50 \%$ (e.g., Golde, 2005; Walker, Golde, Jones, Bueschel, \& Hutchings, 2008), is the lowest (Ampaw \& Jaeger, 2011). Researchers are increasingly concerned about the high number of $\mathrm{PhD}$ candidates who fail to graduate as dropping out can have numerous negative consequences on PhD students (Levecque, Anseel, De Beuckelaer, Van der Heyden, \& Gisle, 2017; Ali \& Kohun, 2007; Bowman \& Bowman, 1990) and their advisor (Devos, Boudrenghien, Van der Linden, Azzi, et al., 2016). In this context, one line of research has focused on the factors that influence doctoral completion. This research, although interesting, has several limitations that we aimed to address in the present paper. For example, little attention has been devoted to the interaction between different factors associated with doctoral degree completion.

\subsection{Factors Related to Doctoral Completion}

In recent years, a number of studies have been conducted to identify the factors leading to doctoral success. Most of these studies solely relied on qualitative approaches and focused specifically on subjective aspects such as mental health and well-being. In this paper, we present a study that examined the objective aspects associated with doctoral success such as socio-demographic variables, academic achievement indicators, and financial factors. Specifically, we focused on gender, nationality, marital status, undergraduate grade, age, scientific discipline, change of university, change of field of research, and funding. 
Several authors found that men are (slightly) more likely to complete their doctorate than women, sometimes even when other factors are taken into account such as the scientific discipline (Groenvynck, Vandevelde, \& Van Rossem, 2013; Van Ours \& Ridder, 2003; Visser, Luwel, \& Moed, 2007). Other authors found no effect of gender on doctoral completion (Mastekaasa, 2005; Van der Haert, Arias Ortiz, Emplit, Halloin, \& Dehon, 2013; Wright \& Cochrane, 2000; Spronken-Smith, Cameron, \& Quigg, 2018). In an attempt at reconciling these contradictory results, Ampaw and Jaeger (2011) pointed out that studies showing no significant gender differences have used multivariate analyses or included multiple academic fields. They further suggested that confounding factors were at play. In other words, according to these scholars, the issue is not whether or not women graduate at a lower rate than men but whether or not women receive less support and opportunities (e.g., funding) than men.

Nationality is another factor seemingly related to doctoral success. Specifically, studies conducted in the US and Europe found that foreign students enjoyed higher completion rates their "native" counterparts (Espenshade \& Rodriguez, 1997; Groenvynck et al., 2013; Wright \& Cochrane, 2000). However, in Belgium, Van der Haert et al. (2013) found no effect of nationality on completion.

Concerning academic achievement, for PhD students with the highest undergraduate GPA, the rate of completion is five times higher than for students with the lowest grade (Visser et al., 2007; Wright \& Cochrane, 2000). However, in their meta-synthesis, Bair and Haworth (2004) concluded that academic achievement indicators like GPA are not effective predictors of doctoral completion.

Age is another factor which has been related to doctoral completion. The youngest $\mathrm{PhD}$ students at the start of their research career (20-26 years) enjoy higher completion rates than the oldest (27-75 years; Groenvynck et al., 2013; Van der Haert et al., 2013; Wright \& Cochrane, 2000; Spronken-Smith, et al., 2018). However, in their meta-synthesis, Bair and Haworth (2004) concluded that age did not satisfactorily distinguish completers from non-completers.

Contrary to demographic factors, the effect of funding on doctoral completion seems robust. All things being equal (including academic achievement), students who are awarded a fellowship have higher completion rates than students who are awarded an assistantship or who are totally self-supporting (Ampaw \& Jaeger, 2011; Ehrenberg \& Mavros, 1995, 1992). In the Dutch-speaking part of Belgium, Groenvynck et al. (2013) also observed that students awarded a fellowship have higher doctoral completion rates than those awarded an assistantship, but they also found that junior researchers with funding unrelated to fundamental research have the lowest chances of success.

Several studies have shown that doctoral completion varies depending on discipline. Indeed, students in natural sciences, applied sciences and medical sciences are more likely to complete their $\mathrm{PhD}$ than those in arts, humanities and social sciences (Espenshade \& Rodriguez, 1997; Groenvynck, et al., 2013; Seagram, Gould, \& Pyke, 1998; Wright and Cochrane, 2000). However, Van der Haert et al. (2013) observed that the effect of discipline disappears when the type of funding is taken into account.

Although significant effects have been found for all the factors mentioned above, several authors have highlighted that discipline and funding are the most robust predictors of doctoral completion (Groenvynck et al., 2013; Wright and Cochrane, 2000). For example, Spronken-Smith et al. (2018) found that candidates in health sciences had the highest completion rates, whereas candidates in business had the shortest time-to-degree.

\subsection{Limitations of Previous Research}

The literature on doctoral completion is limited in several ways. First, several studies focused on one institution and/or on a limited number of disciplines. Second, most studies solely focused on samples of American PhD students (e.g., Jairam \& Kahl, 2012; De Valero, 2001), which are not necessarily representative of all PhD students across the world. Third, some results are inconsistent (e.g., contradictory results concerning gender), which may be explained by a lack of studies examining interactions effects. Several authors suggested interactions potentially interesting to explore. For example, gender and discipline interact (Ampaw \& Jaeger, 2011; Groenvynck et al., 2013; Mastekaasa, 2005; Visser et al., 2007) as do gender and funding (Ampaw \& Jaeger, 2011). Still with regard to gender, Ampaw and Jaeger (2011) suggested that, for female students, marital status could have an effect on degree completion. Moreover, confounding effects of funding on the relationship between discipline and doctoral completion may be at play, as some disciplines may be more likely to attract more prestigious funding (Groenvynck et al., 2013). Such effects were highlighted in van der Haert et al.'s (2013) study.

Fourth, there is no study investigating the cumulative effect of risk factors on the rate of doctoral completion. Adopting a cumulative risk perspective allows to test whether the number of risk factors faced by a doctoral student is more important for predicting doctoral completion than the type of risk factor (Kolvin, Miller, Fleeting, \& Kolvin, 
1988; Sameroff, Seifer, Baldwin, \& Baldwin, 1993; Rutter, 1979). In addition, very little is known about the crucial period of doctoral completion by using time course analyses.

Finally, it is important to point out that higher education systems are very specific to their countries. In this regard, there is a tendency to overgeneralize the results in the current literature which can lead to neglecting the context and thus to wrong analogies between countries and systems. In other words, lack of cross-country research may lead researchers to overlook such contextual differences, leading to an overgeneralization of the results.

\subsection{The Present Study}

In the present study, we used data from doctoral students enrolled in the two largest French-speaking universities in Belgium. In 2015-2016, these two public universities enrolled more than 50,000 students, including more than 3,200 $\mathrm{PhD}$ students spread across 25 different fields of research. Thus, in contrast to much of the literature, all disciplines in both universities were taken into account.

We first examined completion rates in a large sample of doctoral students from both universities. Based on our literature review, we then investigated the effect of potential predictors of doctoral completion by means of univariate and multivariate analyses. Finally, we explored the cumulative effect of risk factors on the rate of doctoral degree completion and time-to-degree.

\subsection{Objectives}

The first objective of the present study was to analyze the direct and interactive effects of different factors on doctoral success. We propose that several factors will predict the rate of doctoral completion. Specifically, we expect that (1) men will have higher completion rates than women, (2) Belgian PhD students will have lower completion rates than other students (3), younger PhD students (20-26 years) will have higher completion rates than older $\mathrm{PhD}$ students (27-75 years), (4) PhD students with higher GPA grades will have higher completion rates than students with lower grades, (5) students in health sciences and in sciences and technology will have higher completion rates than students in humanities and social sciences, (6) $\mathrm{PhD}$ students without funding will have lower completion rates than funded students..

In addition, we examine the role of other factors such as marital status, whether the student transferred from another university (Note 1), whether the student changed field of research. However, we do not have any strong hypothesis regarding these three specific factors.

Moreover, we expect to find interactions between gender and other variables suggested above such as discipline, funding and marital status. Also, we postulate that there will be interactions between the discipline and funding. However, exploratory interactions analyses will be conducted between all variables.

Furthermore, we expect higher dropout rates among $\mathrm{PhD}$ students who accumulate a greater number of risk factors. Finally, we focused on the time course of doctoral dropout in order to identify the crucial moment of attrition and examine if peak periods of dropouts interact with other key factors such as the source of funding and the type of scholarship. In this context, we postulate that drop-out rates should be higher during the beginning of the thesis and higher among students who do not have funding.

In sum, this study addresses a gap in the current literature by analyzing the associations between the factors of doctoral success and dropout, thus contributing to the debate in this field of research.

\section{Method}

\subsection{Participants}

The analyses presented in this paper were conducted on data from cohorts of PhD students spanning 8 years. Indeed, "although funding for doctoral training is generally limited to four years full-time or six years part-time, eight years is considered an adequate period to assess success or failure" (Groenvynck et al., 2013, p. 201). Participants were $\mathrm{PhD}$ students who started their doctoral process during the academic year 2005-2006 or 2006-2007.

Objective characteristics of the doctoral students and of their working context were collected from the administrative databases of both universities. These databases contain data collected at the registration of the PhD students, but also information related to changes during the doctoral process (e.g., change of marital status, change of funding). The data were anonymized by the administrative services.

\subsection{Dependent Variable}

Whether a student had completed his/her PhD or not was recorded for each year of their doctoral studies. We summarize all these information for each student and compute a variable that assigned doctoral students to one of 
three categories: (0) probably dropped out, (1) success, and (2) probably still active. Given that dropout is not recorded, students who had not succeeded during a specific academic year and who had not registered the following year were considered as "probably dropped out". Doctoral students who had not succeeded but who were still registered during the last year of the database timeframe were labelled as "probably still active".

\subsection{Independent Variables}

Based on our literature review, the following characteristics were analyzed as potential determinants of the dependent variable: gender, nationality, marital status, master grade, same university for the undergraduate degree and for the doctoral degree, same field for the undergraduate degree and for the doctoral degree, age at registration, research fields and funding.

Gender. This variable is coded 0 if male and 1 if female.

Nationality. PhD students are grouped in one of three categories: (1) Belgian nationals, (2) nationals from another EU country and (3) non-EU nationals.

Marital status. This variable is coded 0 if married and 1 if unmarried. This information is missing for $8.7 \%$ of the $\mathrm{PhD}$ students in the sample.

Master grade. The master grade is the grade obtained upon graduating from the masters' program. Information on grades was missing for $35.5 \%$ of the $\mathrm{PhD}$ students in the sample, partly due to the use of pass/fail grading in some disciplines. The other $64.5 \%$ of the participants were assigned to one of four categories: (1) satisfactory (satis bene), (2) distinction (cum laude), (3) high distinction (magna cum laude), (4) the highest distinction (summa cum laude).

Changing university. This variable was coded 0 when $\mathrm{PhD}$ students were enrolled at the same university as the one which awarded them their Master degree, and 1 otherwise. This information was missing for $2.3 \%$ of the $\mathrm{PhD}$ students in the sample.

Change in field between the undergraduate and doctoral degree. This variable was coded 1 when $\mathrm{PhD}$ student changed field of research between their Master degree and their $\mathrm{PhD}$, and 0 otherwise. This information was missing for $3.5 \%$ of the $\mathrm{PhD}$ students in the sample.

Age at registration. Age at registration was defined as the age at the time of the first year of registration as a $\mathrm{PhD}$ student. PhD students were assigned to one of three categories: (1) less than 26 years old, (2) between 26 and 40 years old and (3) more than 40 years old.

Research field. All research fields were clustered into four disciplines: (1) humanities, (2) social sciences, (3) health sciences, and (4) science and technology.

Funding. All fundings were grouped into four categories: (1) research grants (i.e., students doing their $\mathrm{PhD}$ in the framework of a research project that takes them on as researchers, and not necessarily as PhD students), (2) assistantships (i.e., PhD students who spend on average 50\% of their time on research and 50\% on teaching), (3) competitive fellowships; (4) no-funding or unknown funding.

Finally, given the large number of missing values for some variables, we relied on pairwise deletions of missing data, which partly accounts for discrepancies in $N$ across the results section.

\section{Results}

\subsection{Prevalence Analysis}

Table 1 presents the number of PhD students depending on whether they succeeded, dropped out or were still active within a period of eight years.

Table 1. Rates of doctoral completion and dropout within a period of 8 years

\begin{tabular}{lcc}
\hline & Frequency & Percent \\
\hline Success & 820 & $54.3 \%$ \\
Probably dropped out & 572 & $37.9 \%$ \\
Probably still active & 117 & $7.8 \%$ \\
Total & 1509 & $100 \%$
\end{tabular}

All the analyses that follow will focus on the explanation of two of these three categories, namely "probably dropped out" and "success". The PhD students who were probably still active were excluded from the subsequent analyses. 


\subsection{Simple Comparisons}

In this first part of our analyses, the factors associated with success and dropout were studied separately using logistic regression analyses with the coded contrasts. Dummy variables were created for all the categorical variables. Table 2 aggregates success rates as a function of each factor.

Table 2. Success rates as a function of factors

\begin{tabular}{|c|c|c|c|c|c|}
\hline & Frequency & Success rate & & Frequency & Success rate \\
\hline Gender & & & Marital status & & \\
\hline Male & 779 & $60.6 \%$ & Married & 376 & $67.3 \%$ \\
\hline Female & 613 & $56.8 \%$ & Unmarried & 946 & $53.7 \%$ \\
\hline Nationality & & & Age & & \\
\hline Belgian nationals & 841 & $62.5 \%$ & $\begin{array}{l}\text { Lower than } 26 \\
\text { years old }\end{array}$ & 669 & $65.6 \%$ \\
\hline $\begin{array}{l}\text { Nationals from another EU } \\
\text { country }\end{array}$ & 255 & $56.9 \%$ & $\begin{array}{l}\text { Between } 26 \\
\text { and } 40 \text { years } \\
\text { old }\end{array}$ & 637 & $55.1 \%$ \\
\hline Non-EU nationals & 296 & $50.3 \%$ & $\begin{array}{l}\text { Higher than } 40 \\
\text { years old }\end{array}$ & 86 & $34.9 \%$ \\
\hline Master grade & & & Research field & & \\
\hline Summa cum laude & 150 & $81.3 \%$ & $\begin{array}{l}\text { Sciences and } \\
\text { technologies }\end{array}$ & 555 & $68.6 \%$ \\
\hline Magna cum laude & 456 & $62.1 \%$ & Health sciences & 278 & $59.4 \%$ \\
\hline Cum laude & 256 & $49.2 \%$ & Social sciences & 362 & $49.4 \%$ \\
\hline Success without honors & 26 & $34.6 \%$ & Humanities & 197 & $48.2 \%$ \\
\hline University & & & Field & & \\
\hline Same university & 745 & $62 \%$ & Same field & 1064 & $61 \%$ \\
\hline Different university & 616 & $56 \%$ & Different field & 281 & $54.8 \%$ \\
\hline \multicolumn{6}{|l|}{ Funding } \\
\hline Fellowship & 351 & $80.1 \%$ & Research grant & 308 & $64 \%$ \\
\hline Assistantship & 170 & $67.6 \%$ & $\begin{array}{l}\text { No- or unknown } \\
\text { funding }\end{array}$ & 563 & $40.3 \%$ \\
\hline
\end{tabular}

\subsection{Gender}

The relationship between doctoral success/dropout and gender was statistically non significant $\left(X^{2}(1)=2.07 ; \mathrm{p}>.05\right)$. However, from a purely descriptive standpoint, success rates tended to be higher among men than among women (see Table 2).

\subsection{Nationality}

The relationship between doctoral success/dropout and nationality was significant $\left(X^{2}(2)=14.02 ; p<.01\right)$ (Cramer's $V=.10 ; p<.01)$. More specifically, the regression analyses conducted to identify the specific impact of each category show that the contrasts of the category of reference (i.e., Belgian nationals) with the category "Non-EU nationals" is significant $(\beta=-.50 ; S D=.14$; Wald $=13.41 ; d f=1 ; p<.001 ; \mathrm{OR}=.61)$, but not the one with the category "Nationals from another EU country" $(\beta=-.24 ; S D=.15$; Wald $=2.66 ; d f=1$; n.s.; OR $=.79)$. In other words, Belgian nationals have a higher rate of doctoral degree completion as compared to Non-EU nationals (see Table 2).

\subsection{Marital Status}

The relationship between doctoral success/dropout and marital status was significant $\left(X^{2}(1)=20.34 ; p<.001\right.$; Cramer's $V=.12$ ) suggesting that the success rate is higher among people who are married (see Table 2). 


\subsection{Age at Registration}

The relationship between doctoral success/dropout and age at registration is significant $\left(X^{2}(2)=36.77 ; p<.001\right.$; Cramer's $V=.16$ ). More specifically, the regression analyses conducted to identify the specific impact of each category show that the contrasts of the reference category (i.e., lower than 26 years) (1) with the category "between 26 and 40 years old" $(\beta=-.44 ; S D=.11$; Wald $=15.04 ; d f=1 ; p<.001 ; \mathrm{OR}=.64)$ and $(2)$ with the category "more than 40 years old" $(\beta=-1.27 ; S D=.24 ;$ Wald $=27.92 ; d f=1 ; p<.001 ; \mathrm{OR}=.28)$ are significant. In sum, younger $\mathrm{PhD}$ students have a higher rate of doctoral degree completion (see Table 2).

\subsection{Master Grade}

The relationship between doctoral success/dropout and master grade was significant $\left(X^{2}(3)=48.73 ; p<.001\right.$; Cramer's $V=.23)$. More specifically, the regression analyses conducted to identify the specific impact of each category show that the contrasts of the category of reference (i.e., high distinction) (1) with the category "satisfactory" $(\beta=-1.13 ; S D=.42$; Wald $=7.10 ; d f=1 ; p<.01 ; \mathrm{OR}=.32)$, (2) with the category "distinction" $(\beta=-.52 ; S D=.16$; Wald $=10.98 ; d f=1 ; p<.01 ; \mathrm{OR}=.59)$ and (3) with the category "very high distinction" $(\beta=.98 ; S D=.23$; Wald $=18.03 ; d f=1 ; p<.001 ; \mathrm{OR}=2.66)$ are significant. In other words, a higher master grade is associated with a higher rate of doctoral completion.

\subsection{Changing University}

The relationship between doctoral success/dropout and change in university is significant $\left(X^{2}(1)=5.04 ; \mathrm{p}<.05\right)$ (Cramer's $V=.06 ; p<.05$ ) suggesting that pursuing a $\mathrm{PhD}$ in the same university leads to a higher success rate (see Table 2).

\subsection{Changing Field of Research}

Results show a marginal significant relationship between doctoral success/dropout and change of field $\left(X^{2}(1)=3.54\right.$; $p=.06$ ), suggesting that pursuing a $\mathrm{PhD}$ in the same field might lead to a higher success rate (see Table 2).

\subsection{Research Field}

The relationship between doctoral success/dropout and research field is significant $\left(\mathrm{X}^{2}(3)=44.45 ; p<.001\right)$ (Cramer's $V=.18 ; p<.001$ ). More specifically, the regression analyses conducted to identify the specific impact of each category show that the contrasts of the reference category (i.e., science and technology) (1) with the category "humanities" $(\beta=-.86 ; S D=.17$; Wald $=25.46 ; d f=1 ; p<.001$; OR $=.43)$, (2) with the category "social sciences" $(\beta=-.81 ; S D=.14 ;$ Wald $=33.43 ; d f=1 ; p<.001 ; \mathrm{OR}=.45)$ and $(3)$ with the category "health sciences" $(\beta=-.41$; $S D=.15$; Wald $=7.05 ; d f=1 ; p<.01 ; \mathrm{OR}=.67$ ) are significant for each field suggesting that the field of research has an effect on the rate of doctoral degree completion (see Table 2). Specifically, $\mathrm{PhD}$ students in sciences and technology are more likely to complete their $\mathrm{PhD}$ that students from the other disciplines.

\subsection{Funding}

The relationship between doctoral success/dropout and funding is significant $\left(X^{2}(3)=153.83 ; p<.001\right)$ (Cramer's $V$ $=.33 ; p<.001)$. More specifically, the regression analyses conducted to identify the specific impact of each category show that the contrasts of reference category (i.e., no-funding or unknown funding) (1) with the category "assistant lectureship" $(\beta=1.13 ; S D=.19$; Wald $=37.26 ; d f=1 ; p<.001$; $\mathrm{OR}=3.10)$, (2) with the category "fund from outside of university" ( $\beta=1.78 ; S D=.16$; Wald $=125.89 ; d f=1 ; p<.001 ; \mathrm{OR}=5.94)$ and (3) with the category "research project" $(\beta=.97 ; S D=.15$; Wald $=43.46 ; d f=1 ; p<.001$; $\mathrm{OR}=2.63)$ are significant suggesting that $\mathrm{PhD}$ students with no-funding or unknown funding have the lowest rate of doctoral degree (see Table 2).

\subsection{Multivariate Analyses}

Based on these univariate analyses, a multiple logistic regression analysis was conducted in an attempt to obtain a model that identifies factors that, when taken together, may tend to predict successful submission. Only the variables found to be significantly linked to the dependent variable in the univariate analyses were entered in the present multivariate analysis. Table 3 presents the results of this multivariate analysis. 
Table 3. Prediction of doctoral success/dropout for all variables

\begin{tabular}{|c|c|c|c|c|c|c|}
\hline Variables & $\beta$ & $\begin{array}{l}\text { Standard } \\
\text { Deviation }\end{array}$ & Wald & $\begin{array}{l}\text { Degree of } \\
\text { freedom }\end{array}$ & $P$ value & OR \\
\hline $\begin{array}{l}\text { Nationality ("Belgian nationals" versus } \\
\text { "Non-EU nationals") }\end{array}$ & -.28 & .45 & .38 & 1 & .54 & .76 \\
\hline Marital status & -1.47 & .22 & 44.01 & 1 & .00 & .23 \\
\hline $\begin{array}{l}\text { Master grade ("high distinction" versus } \\
\text { "satisfaction") }\end{array}$ & -.32 & .52 & .39 & 1 & .53 & .72 \\
\hline $\begin{array}{l}\text { Master grade ("high distinction" versus } \\
\text { "distinction") }\end{array}$ & -.22 & .20 & 1.26 & 1 & .26 & .80 \\
\hline $\begin{array}{l}\text { Master grade ("high distinction" versus } \\
\text { "very high distinction") }\end{array}$ & .92 & .26 & 12.31 & 1 & .00 & 2.50 \\
\hline $\begin{array}{l}\text { Change of university between undergraduate } \\
\text { and doctoral degree }\end{array}$ & -.16 & .23 & .51 & 1 & .48 & .85 \\
\hline $\begin{array}{l}\text { Age at registration ("less than } 26 \text { years old" } \\
\text { versus "between } 26 \text { and } 40 \text { years old") }\end{array}$ & .22 & .21 & 1.13 & 1 & .29 & 1.25 \\
\hline $\begin{array}{l}\text { Age at registration ("less than } 26 \text { years old" } \\
\text { versus "strictly more than } 40 \text { years old") }\end{array}$ & -.80 & .48 & 2.77 & 1 & .10 & .45 \\
\hline $\begin{array}{l}\text { Research field ("science and technology" } \\
\text { versus "humanities") }\end{array}$ & -.73 & .26 & 8.13 & 1 & .00 & .48 \\
\hline $\begin{array}{l}\text { Research field ("sciences and technologies" } \\
\text { versus "social sciences") }\end{array}$ & -.20 & .22 & .78 & 1 & .38 & .82 \\
\hline $\begin{array}{l}\text { Research field ("science and technology" } \\
\text { versus "health sciences") }\end{array}$ & -.08 & .23 & .13 & 1 & .72 & .92 \\
\hline $\begin{array}{l}\text { Funding ("no-funding or unknown } \\
\text { funding" versus "assistant lectureship") }\end{array}$ & 1.09 & .26 & 17.07 & 1 & .00 & 2.96 \\
\hline $\begin{array}{l}\text { Funding ("no-funding or unknown } \\
\text { funding" versus "non-university funding") }\end{array}$ & 1.80 & .26 & 48.24 & 1 & .00 & 6.06 \\
\hline $\begin{array}{l}\text { Funding ("no-funding or unknown } \\
\text { funding" versus "research project") }\end{array}$ & .78 & .24 & 10.49 & 1 & .00 & 2.19 \\
\hline Constant & .70 & .31 & 5.09 & 1 & .02 & 2.01 \\
\hline
\end{tabular}

Note: $\mathrm{N}=838 . R^{2}=.21$ (Cox \& Snell), .28 (Nagelkerke). Model $\chi^{2}(14)=195.791, \mathrm{p}<.001$. Percentage of correct classification $=70.2 \%$. Significant effects are presented in bold.

These results show that four factors (marital status, master grade, research field and funding) are directly associated with dropout rate when all factors are considered together in the same model (Note 2).

\subsection{Analysis of Interaction Effects}

Several interaction effects were analyzed, either because they were suggested by our literature review or because they combine factors that we consider to be conceptually related (e.g., gender and marital status). First, a significant interaction was found between gender and marital status $(\beta=-.69 ; S D=.26$; Wald $=6.56 ; d f=1 ; p=.01 ;$ OR $=$ 0.51). When splitting the interaction as a function of gender, regression analyses revealed that marital status predicts success rates among women $(\beta=-.96 ; S D=.2$; Wald $=22.74 ; d f=1 ; p<.001 ; \mathrm{OR}=0.38)$ but not among men $(p>.05)$. Married women have a higher rate of doctoral degree completion as compared to unmarried women. From a purely descriptive standpoint, the tendency is the same for men but the difference is statistically non significant. Success rates as a function of marital status are presented separately for males and females in Table 4.

Second, when transforming research field (reference category: sciences and technologies) and funding (reference category: no-funding or unknown funding) into dummy variables, we found significant interactions between research grant and social sciences $(\beta=1.09 ; S D=.4 ;$ Wald $=7.41 ; d f=1 ; p=.006 ; \mathrm{OR}=2.96)$, on the one hand, and 
between research grant and health sciences $(\beta=-1.1 ; S D=.4$; Wald $=7.45 ; d f=1 ; p=.006$; OR $=.33$ ), on the other hand. When breaking down the interaction, regression analyses revealed that for $\mathrm{PhD}$ students working on a research grant, the sector of health sciences has an important influence on the drop-out rate $(\beta=-1.15 ; S D=.31$; Wald $=14.16 ; d f=1 ; p<.001 ; \mathrm{OR}=.32)$. Turning to $\mathrm{PhD}$ students with no funding, humanities $(\beta=-.8 ; S D=.22$; Wald $=12.64 ; d f=1 ; p<.001 ; \mathrm{OR}=.45)$ and social sciences $(\beta=-.59 ; S D=.25 ;$ Wald $=5.47 ; d f=1 ; p=.019 ; \mathrm{OR}=.55)$ show the highest drop-out rates. Success rates as a function of research field and funding are presented in Table 5.

Third, regression analyses demonstrated an interaction between field of research and nationality (reference category: Belgians) and more precisely, between health sciences and European PhD students $(\beta=-1.5$; $\mathrm{SD}=.43$; Wald $=11.97$; $d f=1 ; p=.001 ; \mathrm{OR}=.22)$ but not with non-European PhD students $(p>.05)$. Splitting the sample as a function of nationality, we found that Belgians tend to have lower completion rates in health sciences $(\beta=-.83 ; S D=.21$; Wald $=16.85 ; d f=1 ; p<.001 ; \mathrm{OR}=.422)$ and social sciences $(\beta=-.67 ; S D=.19 ;$ Wald $=13.22 ; d f=1 ; p<.001 ;$ OR $=.51$ ) than in other fields of research (see Table 6). Europeans have significantly lower completion scores in humanities $(\beta=-1.42 ; S D=.42$; Wald $=11.27 ; d f=1 ; p=.001$; OR $=.24)$, health sciences $(\beta=-1.62 ; S D=.38$; Wald $=17.23 ; d f=1 ; p<.001 ; \mathrm{OR}=.2)$ and social sciences $(\beta=-1.27 ; S D=.36$; Wald $=12.37 ; d f=1 ; p<.001 ; \mathrm{OR}$ $=.28)$ than in science and technology. Finally, Non-Europeans demonstrated the lowest success rate in social sciences $(\beta=-79 ; S D=.28 ;$ Wald $=7.72 ; d f=1 ; p=.005 ; \mathrm{OR}=.45)$.

Fourth, regression analyses showed an interaction between changing university and the category of European $\mathrm{PhD}$ students $(\beta=.89 ; \mathrm{SD}=.37$; Wald $=5.78 ; d f=1 ; \mathrm{p}=.016$; $\mathrm{OR}=2.43)$. Splitting the sample as a function of nationality, we found that changing university predicts greater dropout, but only among European $\mathrm{PhD}$ students $(\beta$ $=.66 ; \mathrm{SD}=.32 ;$ Wald $=4.25 ; d f=1 ; \mathrm{p}=.039 ; \mathrm{OR}=1.93)($ see Table 7$)$.

Table 4. Relationship between gender * marital status on success rate

\begin{tabular}{lllll}
\hline & & Married & & Unmarried \\
\hline & $\mathrm{N}$ & $\begin{array}{l}\text { Success } \\
\text { rate }\end{array}$ & $\mathrm{N}$ & $\begin{array}{l}\text { Success } \\
\text { rate }\end{array}$ \\
\hline Male & 216 & $64.4 \%$ & 532 & $57.5 \%$ \\
\hline Female & 160 & $71.3 \%$ & 414 & $48.8 \%$ \\
\hline
\end{tabular}

Table 5. Relationship between research field * funding on success rate

\begin{tabular}{lllllllll}
\hline & \multicolumn{2}{l}{$\begin{array}{l}\text { Assistant } \\
\text { lectureship }\end{array}$} & $\begin{array}{l}\text { Fund from } \\
\text { outside of } \\
\text { university }\end{array}$ & Research project & $\begin{array}{l}\text { No-funding or } \\
\text { unknown funding }\end{array}$ \\
\hline N & $\begin{array}{l}\text { Success } \\
\text { rate }\end{array}$ & N & $\begin{array}{l}\text { Success } \\
\text { rate }\end{array}$ & N & $\begin{array}{l}\text { Success } \\
\text { rate }\end{array}$ & N & $\begin{array}{l}\text { Success } \\
\text { rate }\end{array}$ \\
\hline Humanities & 10 & $90 \%$ & 42 & $69 \%$ & 28 & $53.6 \%$ & 117 & $35.9 \%$ \\
\hline Social sciences & 55 & $60 \%$ & 31 & $83.9 \%$ & 75 & $76 \%$ & 201 & $31.3 \%$ \\
\hline Health sciences & 31 & $74.2 \%$ & 79 & $81 \%$ & 70 & $42.9 \%$ & 98 & $49 \%$ \\
\hline Sciences and technologies & 74 & $67.6 \%$ & 199 & $81.4 \%$ & 135 & $70.4 \%$ & 147 & $50.3 \%$ \\
\hline
\end{tabular}

Table 6. Relationship between research field * nationality on success rate

\begin{tabular}{lllllll}
\hline & Belgians & \multicolumn{2}{c}{$\begin{array}{l}\text { Europeans } \\
\text { (without Belgians) }\end{array}$} & Non-Europeans \\
\hline & $\mathrm{N}$ & $\begin{array}{l}\text { Success } \\
\text { rate }\end{array}$ & $\mathrm{N}$ & $\begin{array}{l}\text { Success } \\
\text { rate }\end{array}$ & $\mathrm{N}$ & $\begin{array}{l}\text { Success } \\
\text { rate }\end{array}$ \\
\hline Humanities & 128 & $49 \%$ & 40 & $48 \%$ & 29 & $45 \%$ \\
\hline Social sciences & 189 & $54 \%$ & 78 & $51 \%$ & 95 & $39 \%$ \\
\hline Health sciences & 158 & $67 \%$ & 61 & $43 \%$ & 59 & $56 \%$ \\
\hline Sciences and technologies & 366 & $70 \%$ & 76 & $79 \%$ & 113 & $58 \%$ \\
\hline
\end{tabular}


Table 7. Relationship between change university * nationality on success rate

\begin{tabular}{lllllll}
\hline & Belgians & & \multicolumn{2}{l}{$\begin{array}{l}\text { Europeans } \\
\text { (without Belgians) }\end{array}$} & Non-Europeans \\
\hline & $\mathrm{N}$ & $\begin{array}{l}\text { Success } \\
\text { rate }\end{array}$ & $\mathrm{N}$ & $\begin{array}{l}\text { Success } \\
\text { rate }\end{array}$ & $\mathrm{N}$ & $\begin{array}{l}\text { Success } \\
\text { rate }\end{array}$ \\
\hline Same university & 680 & $64 \%$ & 50 & $44 \%$ & 15 & $47 \%$ \\
\hline Other university & 146 & $58 \%$ & 199 & $60 \%$ & 271 & $52 \%$ \\
\hline
\end{tabular}

3.14 Risk Factors Analysis

Each factor that was significantly associated with the outcome in the multiple regression analysis is considered as a risk factor, namely age at registration, nationality, research field, changing university, marital status and the funding $(N=1292)$ (Note 3$)$. Where necessary, each one of these risk factors was recoded so that category 1 corresponds to the category that has a negative impact on doctoral success. A 0 was attributed to the other category(ies). A variable was then created that compute for each $\mathrm{PhD}$ student the number of risk factors he/she accumulated. As presented in Figure 1, and in line with our hypotheses, we observed the highest success rate $(92 \%)$ when there were zero risk factors and the highest drop-out rate (79\%) when six risks had been accumulated. More importantly, the results show a linear progression of drop-out rates as a function of risk factors accumulated with an increase until three years plus a peak at three and six risks.

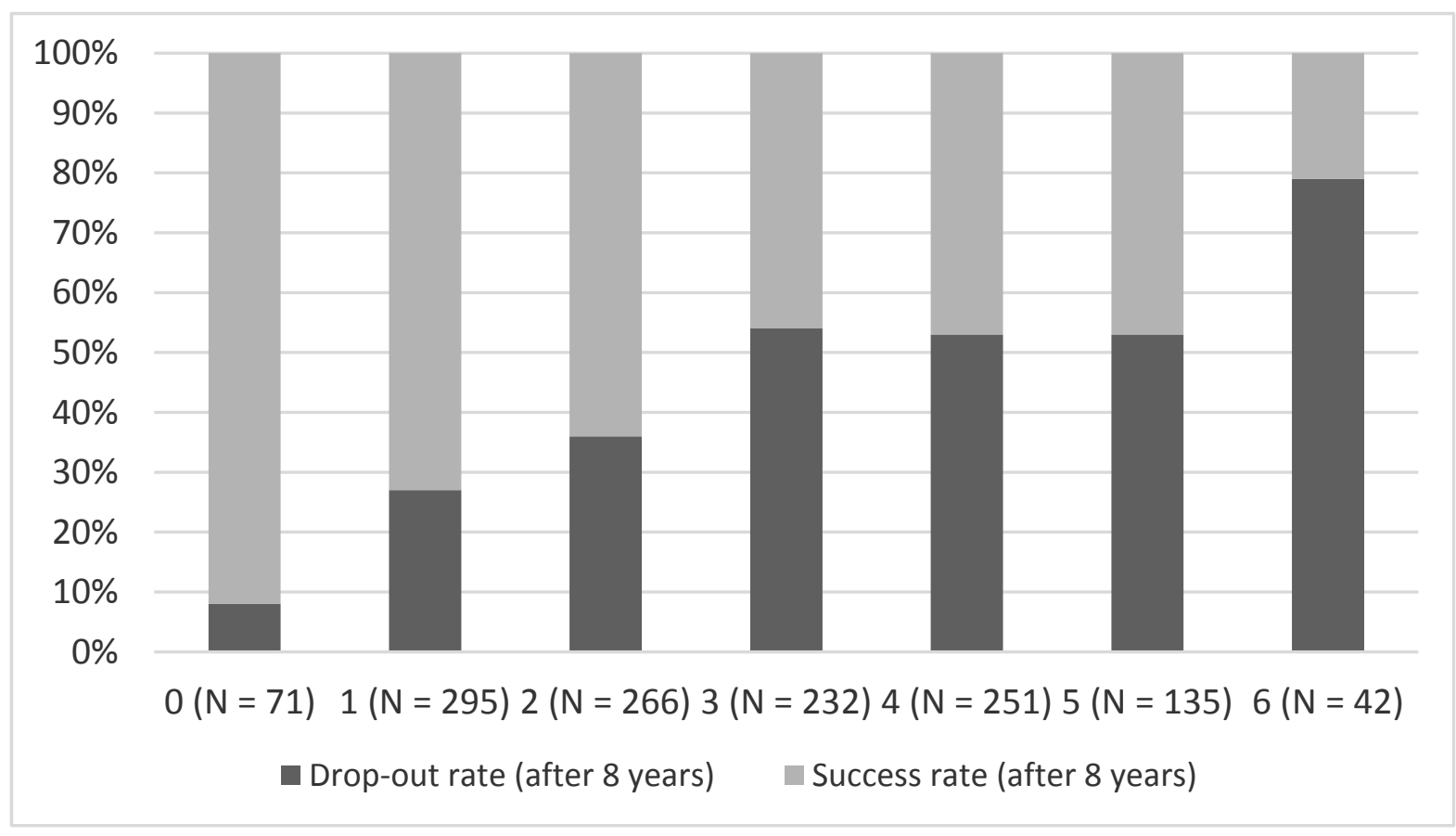

Figure 1. Success and drop-out rates as a function of the number of risk factors accumulated

\subsection{Time Course Analysis}

We also examined when PhD students drop-out. More specifically, we hypothesized that dropout rates should be higher during the beginning of the thesis and higher among students who do not have funding. As expected, Figure 2 shows that the majority of PhD students leave in the first two years of their doctoral trajectory. Secondly, and in line with our hypotheses, $\mathrm{PhD}$ students without funding abandon their doctorate much sooner than funded students (e.g., assistant). Another peak is also observed after five years which is not surprising giving that, in Belgium, the typical grant covers a period of four years. Except the increase at year five, the number of $\mathrm{PhD}$ students dropping out decreases across time. 


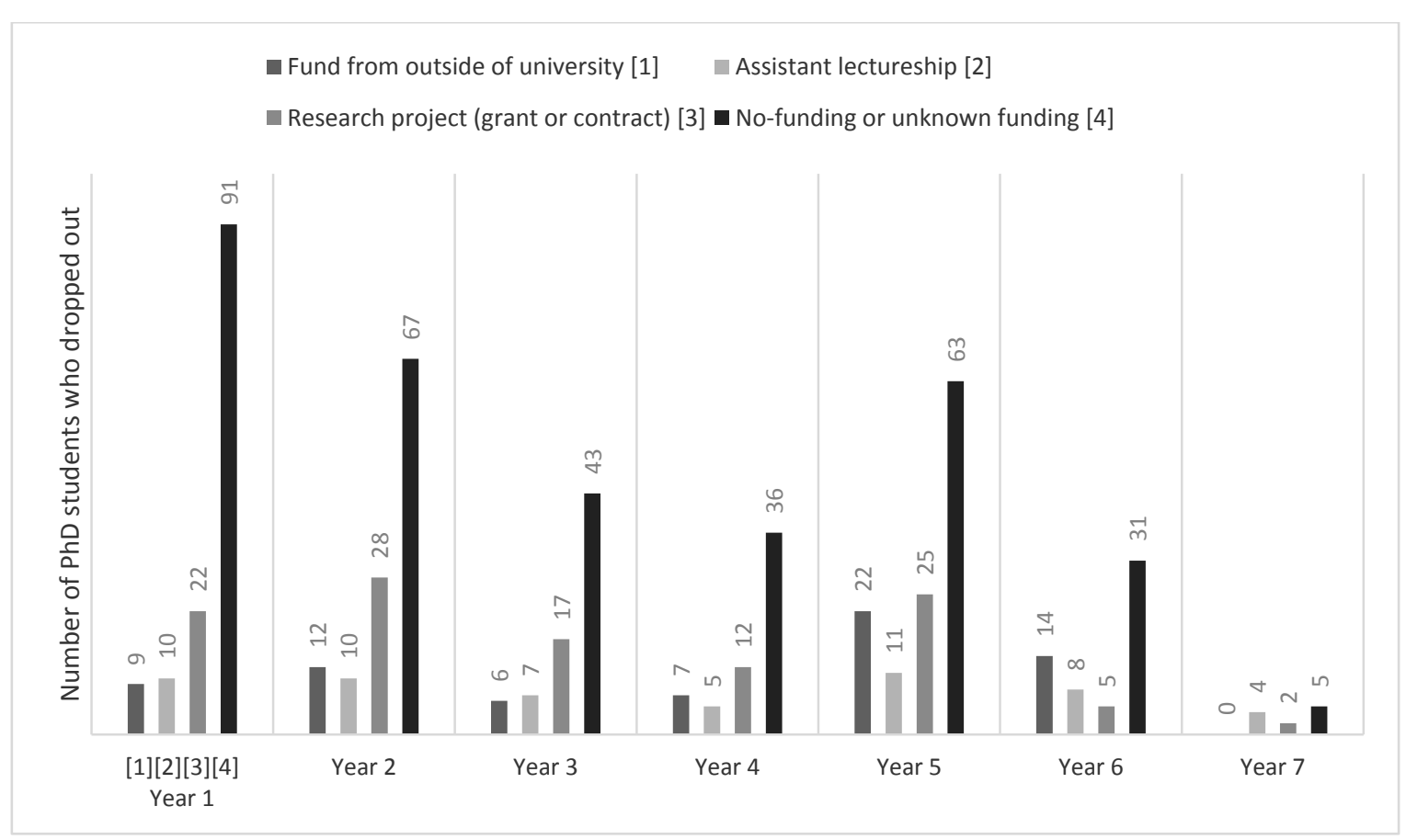

Figure 2. Time course analysis as a function of funding among PhD students who dropped out

\section{Discussion}

While there is a growing body of research on doctoral-related issues, few studies focus on predictors of doctoral completion in non-U.S. countries, across multiple universities and fields of research. Moreover, there is a gap in the current literature regarding potential interactions between predictors as well as the cumulative effect of risk factors. The present paper aimed to address these limitations and analyzed the population of doctoral students from all disciplines at the two largest universities of the French-speaking Community of Belgium.

Across both universities, approximately $50 \%$ of doctoral students obtained a $\mathrm{PhD}$ within a period of eight years, a rate quite similar to the ones observed in English-speaking countries (e.g., Golde, 2005). Which factors are associated with this phenomenon? Seven variables are linked to doctoral success/dropout in our sample: nationality, marital status, master grade, age at registration, research field, continuing at the same university, and funding. Among these, four remained significant when all the predictors were introduced together in the same model. These four factors were: marital status, master grade, research field and funding. Before discussing each one in turn, it should be noted that funding and research field also predicted doctoral completion in Groenvynck et al. (2013) and in Wright and Cochrane (2000; see also Van der Haert et al., 2013).

In the present study, marital status is one of the four most important factors of doctoral success and dropout. Our results confirm what Lott, Gardener, and Powers (2009) and Lovitts (2001) have already observed: married students, or more generally students who are in a relationship, are more likely to complete their PhD within 8 years. Second, consistent with the reports of Visser et al. (2007) and Wright and Cochrane (2000), students who graduated with the highest master grades are more likely to complete their $\mathrm{PhD}$ within 8 years.

Third, as observed by other authors, students with assistant lectureships are less likely to complete their $\mathrm{PhD}$ within 8 years than students who receive research assistantships or doctoral scholarships (Ampaw \& Jaeger, 2011; Ehrenberg, Ronald, Panagiotis, \& Mavros, 1995; Groenvynck et al., 2013). However, our analyses show that this result depends on the type of funding. Indeed, although students with doctoral scholarships for fundamental or applied research both have higher completion rates than those with assistant lectureships (which is the opposite of what Groenvynck et al. [2013] observed), those with doctoral scholarships from their home university have one of the lowest completion rates. Furthermore, results indicate that funding is associated with the degree of doctoral completion differently based on the field of research.

Finally, a PhD student's research field appears to have an effect on doctoral success/dropout (Espenshade \& Rodriguez, 1997; Groenvynck, et al., 2013; Seagram et al., 1998; Van der Haert et al., 2013; Wright \& Cochrane, 2000). Consistent with what has been previously observed, the four sectors can be classified as followed (from 
lowest to highest completion rate): social sciences, humanities, health sciences, science and technology.

Besides the four most important predictors cited above, three variables predict doctoral success/dropout, but do not remain significant in both university samples when all the factors were introduced together in the model. First, as reported by several authors, the nationality of $\mathrm{PhD}$ students is linked to their doctoral success/dropout (Espenshade \& Rodriguez, 1997; Groenvynck et al., 2013; Wright \& Cochrane, 2000). However, our results contradict the existing literature saying that foreign students outperform their native counterparts. In fact, we found that Belgian students are more likely to complete their $\mathrm{PhD}$ within 8 years than foreign students. Additionally, this effect was also heavily influenced by the field of research.

Second, our results confirm that the younger the students are at the start of their doctoral journey, the more likely they are to complete their PhD within 8 years (Groenvynck et al., 2013; Van der Haert et al., 2013; Wright \& Cochrane, 2000).

Furthermore, we found that a change in university increases the risk of doctoral failure, which is consistent with what has been observed by Van Ours and Ridder (2003). However, there was an opposite relationship for Europeans PhD students in our sample. Note that it is difficult to draw conclusions from the latter result because we cannot compare dropout rates to that of Europeans who stayed in their own countries.

The two last variables, namely gender and change in field were not stably significant or not significant at all. First, gender does not predict doctoral success/dropout in our sample. Interestingly, and as stated above, married women (but not men) have a higher success rate than unmarried $\mathrm{PhD}$ students. In this regard, our results did not confirm the idea that men are more successful than women (Groenvynck et al., 2013; Van Ours \& Ridder, 2003; Visser et al., 2007), although no such differences have been found in other studies (e.g., Baker, 1998; Ehrenberg \& Mavros, 1995).

One variable that did not have an effect on the drop-out in this study is the change of field between undergraduate and doctoral degree. On the contrary, the conclusions from Van Ours and Ridder (2003) was expanded to all research fields. Indeed, all fields taken together, we observe that students who do not change of field between undergraduate and doctoral degree are more likely to complete their $\mathrm{PhD}$ within 8 years but the effect was only marginally significant.

In a second step, we investigated whether these factors of doctoral success and dropout, taken together, may constitute a risk for PhD dropout. To our knowledge, the cumulative effect of risk factors has not yet been studied in the literature. More precisely, and in line with our hypotheses, we observed a linear progression of dropout rates as a function of risk factors accumulated with a peak at three factors suggesting that $\mathrm{PhD}$ students who face three or more unfavorable determinants have at least a 50\% risk of dropping out.

Furthermore, we examined when the rate of doctoral degree failure is the most important. To do so, a time course analysis revealed that the two first years are crucial as it is when the vast majority of $\mathrm{PhD}$ dropouts occurs. Again, this is consistent with our hypothesis. More precisely, the higher dropout rate during the first two years can be explained by the absence of funding or scholarship. Our approach confirms previous findings in the literature (e.g., Ampaw \& Jaeger, 2011; Ehrenberg \& Mavros, 1995; Van der Haert et al., 2013).

\subsection{Limitations}

Three limitations to the present study are worth highlighting. First, the effects measured in the regression analysis are statistical effects, and should not be confused with an analysis of causal relationships between dependent and independent variables. This is why this study is only a part of a larger research program that analyzed the effects of a larger number of variables through survey techniques and interviews (Devos et al., 2016; Devos, Boudrenghien, Van der Linden, Frenay, et al., 2016; Devos et al., 2015; Van der Linden et al., 2018).

Second, the present study tries to understand the occurrence of completion within 8 years, but it does not analyze the actual time to completion and time to dropout. However, the "measure of" and the "speed of" the doctoral process appear to be strongly related (Groenvynck et al., 2013). Students who are likely to take a long time to graduate are also more likely to drop out (Van Ours \& Ridder, 2003). Moreover, the study of the "speed of" is probably less relevant in countries like Belgium where most of the $\mathrm{PhDs}$ are supported by funding that have a defined duration.

Third, we do not have a balanced comparison condition for foreign doctoral students (i.e., we cannot compare them to students in their native country), which can lead to confounds the status of foreign doctoral students being more strongly associated with a change in university.

Fourth, the analyses are limited to sociodemographic variables. It could be interesting to include other variables such as psychosocial factors (motivation, engagement, support, etc.). 


\subsection{Implications}

The issue of considerable dropout rate in doctoral programs is well documented across a large number of countries. The associations found in the present study between enrich the current literature and leads to specific implications for research, policy and practices.

Research. The majority of studies focusing on factors predicting doctoral attrition does not take interactions into account. This study overcomes this limitation and addresses several interactions suggested by the current literature (e.g., gender and marital status, Ampaw \& Jaeger, 2011). Interestingly, we found that while some factors have no significant direct effect on doctoral completion (e.g., gender), they strongly moderate the effect of other factors (e.g. marital status). In this regard, we invite scholars to step outside of the typical analysis of main effects made by the current literature and start considering two-way and three-way interactions. Furthermore, we encourage researchers to focus on multiple fields of research, universities and ethnicities in order to enrich the range of population in terms of its socio-demographic characteristics.

Policy. Dropping out can have numerous negative psychological and financial consequences on $\mathrm{PhD}$ students and their advisor, as well as for their institutions. However, there is still a disconnection between the reality of the field and politics. Specifically, there is a growing body of research focusing on the predictors associated with doctoral dropout but there is insufficient discussion of these results within the academic environment and politics. In this regard, we invite researchers to spread and convey such findings to students, $\mathrm{PhD}$ students, professors, academics and so on. For instance, issues such as the lack of training that researchers are offered when entering academic funding (Halse, 2011; Lee, Dennis \& Campbell, 2007) or the degree of fit between supervisory behavior and students' expectation and needs (Pyhältö et al., 2012) should be more widely presented and debated in different kinds of conferences and meetings.

Practices. Within Belgian universities, multiple actions are taking place for advisors and $\mathrm{PhD}$ students such as training, mentoring, tutoring, coaching, workshops, guides and brochures. Given the discrepancies in the rate of doctoral dropout among specific population (e.g., ethnicity, age, gender), this study offers the possibility to adapt our knowledge to identify key factors associated with success and dropout among each group specifically thus allowed us to shape our actions to be more effective. It implies that the effectiveness of these actions should be more carefully evaluated.

\subsection{Conclusion}

To conclude, this study is one of the first that addresses the factors associated with doctoral completion among Non-U.S. countries, multiple universities and fields of research. In fact, this paper focuses on factors associated with doctoral completion from all the disciplines of the two largest universities of the French-speaking Community of Belgium. Moreover, the large number of participants $(\mathrm{N}=1509)$ allowed this research to consider relations between predictors together (e.g., interactions). In addition, we found that accumulation of risk factors leads to a higher dropout rates. Likewise, a time course analyses revealed that the highest dropout rate occurs during the first two years of the PhD process. Finally, we recommend combining qualitative and quantitative approaches in order to find out why some factors such as marital status and funding affect doctoral dropout. More precisely, studying the underlying mechanisms of these effects would bolster the current knowledge in the literature and thus contributing to the debate in this field of research.

\section{Acknowledgement}

We dedicate this work to the memory of Pr. Pambu Kita-Phambu $\dagger$, who contributed to the collection of the data presented in this study, and tragically passed away during the preparation of this manuscript.

This study has been partially supported by a grant from the FRS-FNRS (Fund for Scientific Research) for the project RoPe "Research on PhD" and by the Fédération Wallonie-Bruxelles. Finally, the authors thank Marie Welsh for her assistance with data collection.

\section{References}

Ali, A., \& Gregg Kohun, F. (2006). Dealing with Isolation Feelings in IS Doctoral Programs. International Journal of Doctoral Studies, 1, 021-033. https://doi.org/10.28945/58

Ali, A., \& Gregg Kohun, F. (2007). Dealing with Social Isolation to Minimize Doctoral Attrition - A Four Stage Framework. International Journal of Doctoral Studies, 2, 033-049. https://doi.org/10.28945/56

Ampaw, F. D., \& Jaeger, A. J. (2011). Understanding the factors affecting degree completion of doctoral women in the science and engineering fields. New Directions for Institutional Research, 2011(152), 59-73. 
https://doi.org/10.1002/ir.409

Bair, C. R., Grant Haworth, J., \& Sandfort, M. (2004). Doctoral Student Learning and Development: A Shared Responsibility. Journal of Student Affairs Research and Practice, 41(4). https://doi.org/10.2202/1949-6605.1395

Baker, J. G. (1998). Gender, race and PhD. completion in natural science and engineering. Economics of Education Review, 17(2), 179-188. https://doi.org/10.1016/s0272-7757(97)00014-9

Bowman, R. L., \& Bowman, V. E. (1990). Mentoring in a graduate counseling program: Students helping students. Counselor Education and Supervision, 30, 58-65. https://doi.org/10.1002/j.1556-6978.1990.tb01179.x

Devos, C., Boudrenghien, G., Van der Linden, N., Assaad, A., Frenay, M., Galand, B., \& Klein, O. (2016). Doctoral students' experiences leading to completion or attrition: a matter of sense, progress and distress. European Journal of Psychology of Education. 32(1), 61-77. https://doi.org/10.1007/s10212-016-0290-0

Devos, C., Boudrenghien, G., Van der Linden, N., Frenay, M., Azzi, A., Galand, B., \& Klein, O. (2016). Misfits between doctoral students and their supervisors: (How) Do they regulate? International Journal of Doctoral Studies, 11, 467-486. https://doi.org/10.28945/3621

Devos, C., Van der Linden, N., Boudrenghien, G., Assaad, A., Frenay, M., Galand, B., \& Klein, O. (2015). Doctoral supervision in the light of the three types of support promoted in self-determination theory. International Journal of Doctoral Studies, 10, 438-464. https://doi.org/10.28945/2308

De Valero, Y. F. (2001). Departmental Factors Affecting Time-to-Degree and Completion Rates of Doctoral Students at One Land-Grant Research Institution. The Journal of Higher Education, 72(3), 341. https://doi.org/10.2307/2649335

Ehrenberg, R.G., \& Mavros, P. (1992). Do doctoral students' financial support patterns affect their time-to-degree and completion probabilities. NBER Working Paper No. 4070, Cambridge, MA: National Bureau of Economic Research. https://doi.org/10.3386/w4070

Ehrenberg, R. G., \& Mavros, P. (1995). Do doctoral students' financial support patterns affect their times-to-degree and completion probabilities? Journal of Human Resources, 30, 581-609. https://doi.org/10.2307/146036

Espenshade, T. J., \& Rodríguez, G. (1997). Completing the PhD.: Comparative performances of U.S. and foreign students. Social Science Quarterly, 78(2), 593-605.

Golde, C. M. (2000). Should I Stay or Should I Go? Student Descriptions of the Doctoral Attrition Process. The Review of Higher Education, 23(2), 199-227. https://doi.org/10.1353/rhe.2000.0004

Golde, C. M. (2005). The Role of the Department and Discipline in Doctoral Student Attrition: Lessons from Four Departments. The Journal of Higher Education, 76(6), 669-700. https://doi.org/10.1080/00221546.2005.11772304

Groenvynck, H., Vandevelde, K., \& Van Rossem, R. (2013). The PhD track: Who succeeds, who drops out? Research Evaluation, 22(4), 199-209. https://doi.org/10.1093/reseval/rvt010

Halse, C. (2011). 'Becoming a supervisor': The impact of doctoral supervision on supervisors' learning. Studies in Higher Education, 36(5), 557-570. https://doi.org/10.1080/03075079.2011.594593

Jairam, D., \& H. Kahl Jr., D. (2012). Navigating the Doctoral Experience: The Role of Social Support in Successful Degree Completion. International Journal of Doctoral Studies, 7, 311 - 329. https://doi.org/10.28945/1700

Kolvin, I., Miller, F. J. W., Fleeting, M., \& Kolvin, P. A. (1988). Risk/protective factors for offending with particular reference to deprivation. In M. Rutter (Ed.), Studies of psychosocial risk: The power of longitudinal data. 77-95. New York: Cambridge University Press

Lee, A., Dennis, C., \& Campbell, P. (2007). Nature's guide for mentors. Nature, 447(7146), $791-797$. https://doi.org/10.1038/447791a

Levecque, K., Anseel, F., De Beuckelaer, A., Van der Heyden, J., \& Gisle, L. (2017). Work organization and mental health problems in PhD students. Research Policy, 46(4), 868-879. https://doi.org/10.1016/j.respol.2017.02.008

Lott, J. L., Gardner, S., \& Powers, D. A. (2009). Doctoral Student Attrition in the Stem Fields: An Exploratory Event History Analysis. Journal of College Student Retention: Research, Theory \& Practice, 11(2), 247-266. https://doi.org/10.2190/cs.11.2.e

Lovitts, B. E. (2001). Leaving the Ivory Tower: The causes and consequences of departure from doctoral study. 
Lanham, MD: Rowman \& Littlefield.

Mastekaasa, A. (2005). Gender differences in educational attainment: the case of doctoral degrees in Norway. British Journal of Sociology of Education, 26(3), 375-394. https://doi.org/10.1080/01425690500128908

Pyhältö, K., Vekkaila, J., \& Keskinen, J. (2012). Exploring the fit between doctoral students' and supervisors' perceptions of resources and challenges vis-à-vis the doctoral journey. International Journal of Doctoral Studies, 7, 395-414. https://doi.org/10.28945/1745

Sameroff, A. J., Seifer, R., Baldwin, A., \& Baldwin, C. (1993). Stability of Intelligence from Preschool to Adolescence: The Influence of Social and Family Risk Factors. Child Development, 64(1), 80. https://doi.org/10.2307/1131438

Seagram, B. C., Gould, J., \& Pyke, S. W. (1998). An investigation of gender and other variables on time to completion of doctoral degrees. Research in Higher Education, 39(3), 319-335. https://doi.org/10.1023/a:1018781118312

Spronken-Smith, R., Cameron, C., \& Quigg, R. (2017). Factors contributing to high PhD completion rates: a case study in a research-intensive university in New Zealand. Assessment \& Evaluation in Higher Education, 43(1), 94-109. https://doi.org/10.1080/02602938.2017.1298717

Rutter, M. (1979). Protective factors in children's responses to stress and disadvantage. In M. W. Kent \& J. E. Rolf (Eds.), Primary prevention of psychopathology: Vol. 3. Social competence in children. 49-74. Hanover, NH: University Press of New England

Van der Haert, M., Arias Ortiz, E., Emplit, P., Halloin, V., \& Dehon, C. (2013). Are dropout and degree completion in doctoral study significantly dependent on type of financial support and field of research? Studies in Higher Education, 39(10), 1885-1909. https://doi.org/10.1080/03075079.2013.806458

Van der Linden, N., Devos, C., Boudrenghien, G., Frenay, M., Azzi, A., Klein, O., \& Galand, B. (2018). Gaining insight into doctoral persistence: Development and validation of Doctorate-related Need Support and Need Satisfaction short scales. Learning and Individual Differences, 65, 100-111. https://doi.org/10.1016/j.lindif.2018.03.008

Van Ours, J. C., \& Ridder, G. (2003). Fast track or failure: a study of the graduation and dropout rates of Ph D students in eonomics. Economics of Education Review, 22(2), 157-166. https://doi.org/10.1016/s0272-7757(02)00029-8

Visser, M. S., Luwel, M., \& Moed, H. F. (2006). The attainment of doctoral degrees at Flemish Universities: a survival analysis. Higher Education, 54(5), 741-757. https://doi.org/10.1007/s10734-006-9021-9

Walker, G. E., Golde, C. M., Jones, L., Conklin Bueschel, A., \& Hutchins, P. (2008). The formation of scholars. San Francisco, CA: JosseyBass.

Wright, T., \& Cochrane, R. (2000). Factors Influencing Successful Submission of PhD Theses. Studies in Higher Education, 25(2), 181-195. https://doi.org/10.1080/713696139

\section{Notes}

Note 1. Note that in Belgium, the doctoral stage occurs after two cycles of studies: bachelor (3 years) and master (2 years). In the present paper, we refer to the first two stages as "undergraduate".

Note 2. It has been noted that given the large percentage of missing values for the master grade variable which considerably reduced the number of participants in the multivariate analyses, we conducted the same analysis without this variable. Doing so, results show that one additional factor (age at registration) is associated with dropout rate when all factors are considered together in the same model $\left(\mathrm{N}=1292 . R^{2}=.17\right.$ (Cox \& Snell), 23 (Nagelkerke). Model $\chi^{2}(11)=237.09, p<.001$. Percentage of correct classification $\left.=67.8 \%\right)$.

Note 3. It has been noted that given the large percentage of missing values for the master grade variable which considerably reduced the number of participants, we conducted the risk factor analysis without this variable. However, when including the master grade variable as a risk factor, the results show a similar linear progression of drop-out rates as a function of risk factors accumulated. However, the two last bars contain only 6 and 2 participants respectively $(N=838)$. 